\title{
Triffin Dilemma and International Monetary System : Evidence from Pooled Mean Group Estimation
}

\author{
Long-Fei Guan ${ }^{1}$, Wee-Yeap Lau ${ }^{2}$
}

Received: September 5, 2017. Revised: April 12, 2018. Accepted: May 5, 2018

\begin{abstract}
This study is motivated based on concern from some renowned scholars and central bankers whom have raised the issue of the sustainability of the International Monetary System (IMS). Using the panel data set of four major international currencies, USD, JPY, EUR and GBP from 1973 to 2013 with Pooled Mean Group (PMG) estimator, to re-examine whether Triffin dilemma still exists through investigating the relationship between the reserve share, current account balance and real effective exchange rate. The evidence from the result indicates that Triffin dilemma exists only in the long run, and shows that in the long-run, current account balance is proportionate to the increased real effective exchange rate while varies inversely with the reserve shares. However, the estimation for the short-run is not significant to prove the existence of Triffin dilemma. In addition, we investigated the non-dollar panel sample and found that the international monetary system still suffers from Triffin dilemma even without the dollar. To overcome Triffin dilemma, immediate step such as having currency swap mechanism is recommended. In medium term, a multi-polar Monetary System is suggested, and in the longer time, a supranational currency will be used to replace all the currencies in the world.
\end{abstract}

Keywords: Triffin Dilemma, International Monetary System, Pooled Mean Group, Real Effective Exchange Rate, Current Account Balance, Malaysia.

JEL Classification Code: F33, E42, G15.

\section{Introduction}

In the context of cultural pluralism and globalisation, the world has been changing with each passing day and most of the countries, particularly the developing countries, have been unleashing their potential to achieve economic prosperity. However, economic globalisation has outstepped the development of governmental institutions and rules, especially in the fields of financial and monetary systems (McMillan \& Rodrik, 2011). The 2008 global financial crisis has raised doubt on the sustainability of the international monetary system (IMS) as it exposed the instability of dollar-based international monetary system where the dollar is used as the major international currency (Eichengreen, 2011). Indeed, with the economic

1 First Author, Faculty of Economics and Administration, University of Malaya, Malaysia.

2 Corresponding Author, Faculty of Economics and Administration, University of Malaya [Postal Address: Faculty of Economics and Administration, University of Malaya, 50603 Kuala Lumpur, Malaysia] E-mail: wylau@um.edu.my development of the export-oriented emerging countries for the past few decades, a seemingly unending supply of dollar assets have been put out from the issuing country for use in international trade, storage of value, and accounting units, which has been resulted in the increasing accumulation of dollar reserve in the emerging countries. This is also true for other major international currencies, such as the euro, yen and so on.

In order to hedge the exchange rate risk, the emerging countries like China have purchased a huge amount of the U.S. Treasury bills to build their dollar reserve. This has caused the U.S. domestic cost of capital to sharply decrease, and therefore investment is overheated. Coupled with sense of irrational exuberance by the investors whom are optimistic on the stock market, and also the managers in financial institutions who keep on lending to borrowers irrespective of their credit worthiness have set the stage for the occurrence of Global Financial Crisis in 2008.

To a holding nation, the Federal Reserve and the U.S. government should be blamed for the current state of affairs as they were unable to stabilise the value of the dollar in order to play the role of an international currency. This issue 
has been raised by prominent scholars and central bankers. In a press conference prior to G20 London Summit in March 2009, Governor of the People's Bank of China, Zhou Xiaochuan has called for a reform of the International Monetary System by changing the reserve currency from a single national currency towards an international reserve currency when suggesting a reform plan for the G20 in March 2009. He argued that the current international reserve currency is disconnected from individual countries. In order for the system to remain stable in the long run, there is a need to remove the inherent deficiencies caused by using "credit-based" in its original form: the use of the dollar to finance growing world trade must lead to an increase in short-term the U.S. liabilities that at some point undermine the dollar's link to gold.

Zhao's view is also shared by Padoa-Schioppa (2010), the Italian banker and economist. In his speech on 25 February 2010, he reiterated the need to reexamine Triffin's criticism of an international monetary system:

"....The deep causes of this crisis include the dollar policy and, in a broader sense, the monetary regime that has been in force in the world for almost 40 years. Like the Bretton Woods system, it is incapable of imparting an acceptable macroeconomic discipline to the world's economy because, being devoid of collectively accepted anchors, it encourages the persistence of unsustainable dynamics which spawn increasingly serious crises. Triffin's criticism of an international monetary system based on an exclusively national monetary policy is still valid, although today it demands a broader formulation, capable of taking into account the exchange rate anarchy and a multiplicity of influential monetary policies..."

Both the view of Zhao (2009) and Padoa-Schioppa (2010) have been discussed by McCauley and Schenk (2014) in the BIS Working Papers on Reforming the international monetary system in the 1970s and 2000s. In their paper, they explore the idea of a substitution account that would have allowed central banks to diversify away from the dollar into the IMF's Special Drawing Right (SDR), comprised of US dollar, Deutsche mark, French franc, Japanese yen and British pound, through transactions conducted off the market.

Dating back to 13th August 1971, the United States President Richard Nixon introduced a series of economic measures including unilaterally canceling the direct convertibility of the United States dollars to gold. This action, which was referred as the Nixon shock, brought the Bretton Woods system to an end. In fact, the breakdown of Bretton Wood system was not incidental. Early in the 1960s, there were a number of economists arguing the Dollar-gold- connected Bretton Woods system is defective and unsustainable. Particularly, among of those economists, Triffin (1960) was the best known for the first person to highlight this incompatibility. Triffin predicted the end of Bretton Woods system. In his view, there was an obvious dilemma, having the U.S. dollar perform the role of the international currency created fundamental conflicts of interest between domestic and international economic objectives.

On the one hand, the international economy needed dollars for liquidity purposes and to satisfy the demand for reserve assets. But this forced or at least made it easy, for the U.S. to run consistently large current account deficits. Triffin also argued that such persistent deficits would eventually put pressure on the U.S. dollar and lead to the demise of the Bretton Woods system of international exchange.

Dated back to nowadays, the era of the Bretton Woods system has ended for almost half-century. It is believed that Triffin and his argument is renowned as there has been no sound solution to the dilemma. Just as the Zhou's statement, the underlying contradiction by the Triffin Dilemma still remain for countries of which currency are international. As a result, the country issuing the international currency must supply the currency to the world in order to facilitate world trade and economic growth, and ultimately, the excessive currency supplied will undermine confidence in its value (Eichengreen \& Frankel, 1996) and then have an influence on the entire monetary system and even the global balance.

\subsection{Objective of Study}

In this study, we focus on the classical Triffin dilemma and consider the contradictory relationships between currency supply and current account balance, and currency value as the theoretical framework. Firstly, this study aims to investigate whether the dollar-led international monetary system suffers from Triffin dilemma or not. Secondly, we aim to investigate the existence of Triffin dilemma without the dollar in the international monetary system, and lastly, this study explores an effective path for the prospective development of the international monetary system based on the empirical results.

\subsection{Significance of Study}

This study differs from other literature in two novel ways. Firstly, we focused on a wider range of major currencyissuing countries, not only in countries like the U.S., the UK, and Eurozone. Indeed, as most of the literature only focus on one individual country. Standing from the economic point 
of view, they are somewhat restrictive and from an econometric perspective, they suffer from small sample bias. Secondly, in this study, we improved the power of the traditional co-integration test by combining information from time series and cross-section data in a heterogeneous panel co-integration framework and we generalise the long-run and short-run dynamic relationships among reserve share, current account balance and exchange rate.

This study is organised as follows. Section 2 provides the literature review. Section 3 elaborates the data and methodology. The estimation results are in Section 4. Thereafter, Sections 5 and 6 provide the suggestion and conclusion.

\section{Theoretical Framework}

There are few papers on studying Triffin dilemma with econometrics techniques. However, there are a lot of applied econometric papers discussing on the international monetary system and some other macroeconomic topic related to current account dynamics and currency value. Steiner (2014) provides empirical evidence for a new interpretation on Triffin Dilemma: Central banks' demand for reserves sustains global imbalances. First, reserveaccumulating countries run larger current account balances. Second, the U.S. current account deficit can partly be explained by its reserve currency status. All in all, this literature reflecting the impact of Triffin Dilemma still holds so far and implies a negative relationship between the quantities of currency reserve supply and the current account balance of the issuing states.

However, as the literature has shown, more liquidity means accumulated deficits, which would eventually lead to loss of credibility and eventual devaluation of the key currency. For instance, Obstfeld (2005) asserted that as Asia's trade surplus against the U.S. remains constant, the dollar is depreciating against Asia's currencies. There is an argument, which is that along with the depreciation of the currency that certainly entails central banks to reduce the reserve of the currency. Chinn and Frankel (2007) employ a panel data analysis with the IMF annual data on aggregate central bank holdings of the relevant major currencies. Using the major currencies like the US dollar, Deutsche mark, Euro, Swiss franc and Yen, of which the share of holding is regarded as the dependent variable, they find that loses in the value of a currency decreases the attractiveness of holding it. Besides, Li and Liu (2010) who adopt the same empirical technique also find a positive and significant relationship between currency appreciation and currency share of holding. In other words, depreciation will lead to the decrease of the share of holding for the currency.

\section{Data and Method}

This study uses a strongly balanced panel data set that consists of 4 countries for 41 annual observations during the period between 1973-2013. The four countries are the United States, the United Kingdom, Japan, and Germany (Eurozone). Using the macroeconomic data of Germany as the proxy for the whole Eurozone, Deutsche mark is used prior to 1999 and Euro is used for the remaining sample period. We do not select Switzerland like other relevant literature as we have discussed previously that the Swiss Franc is the neutral currency, of which development is much different from the four countries selected. The data set covers three variables: foreign reserve shares (FRS), current account balance (CA) and real effective exchange rate (REER).

For the foreign reserve shares (FRS) variable, we use currency share of national currencies in total identified official holdings of foreign exchange. The source of data is from IMF Foreign the currency composition of foreign exchange reserves (COFER) database.

The COFER data is divided into two categories: allocated and unallocated reserves. We only focus on the allocated (identified) reserves. As indicated, COFER is a database managed by the IMF's Statistics Department, containing end-of-period quarterly data of reporting countries/ jurisdictions. With the separate identification of reserves in RMB and eight currencies distinguished in COFER data: U.S. dollar; euro; Chinese renminbi; Japanese yen; pound sterling; Australian dollar; Canadian dollar; and Swiss franc.

Following by the adjustment method of Lee (2010), we use the logit transformation of currency share, log (FRS/(1FRS)), to take in consideration of the non-linear relationship between currency share and its determinants. The current account balance (CA) variable is represented by current account balance of the country of which is measured by the current price of a dollar. The data is sourced from the database of Thomson Reuters Datastream.

The current account balance can be negative when it is the deficit; thus, in order to take logit transformation, we modified it by minus the minimum value and plus $1,(1+\mathrm{CA}-$ min (CA)), and then taking the logit transformation. The real effective exchange rate (REER) variable is represented by the real effective exchange rate index and is taken the logit transformation as well. Compared with other relevant literature, the data set is the latest as it continues to 2013. Also, the time span of the dataset used in this study is relatively larger, thereby enabling the estimation reflecting the long-term existed phenomenon more reliable. However, there is a weakness for all empirical research in the field of international currency, likewise to this study, the data set 
being used does not cover the unidentified reserves due to the confidentiality of some central banks.

For the preliminary understanding of the data set, we report the descriptive statistic summary for the three variables untransformed in Table 1 and Table 2 below. Both tables together with Figure 1, it can be shown that the dollar is always the leading currency of the four currencies. The share of pound decreased sharply in 1973 and thereafter tended to flat, however, the mark/Euro and Yen started its expansion and then had the choppy sideways of movement. Until 1999, the Euro was created and its reserve share increased dramatically. Look back to 2013, the U.S. dollar still holds the top and Euro takes the second, following by Pound and Yen.

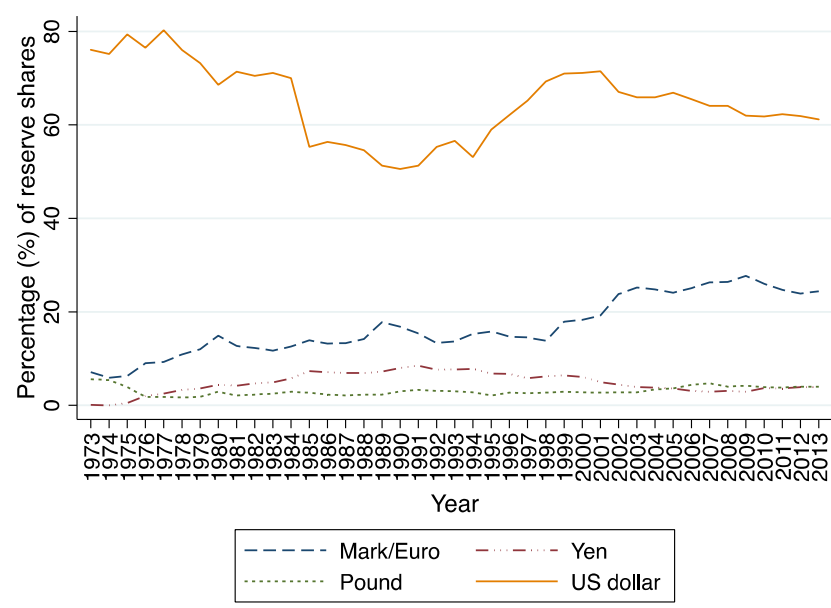

Source: International Monetary Fund, Annual Report (various years); Currency Composition of Official Foreign Exchange Reserves (COFER), available: http://www.imf.org/external /np/sta/cofer/eng/index.htm, downloaded 7 April 2010; author's calculations.

Figure 1. Reserves held by central banks as shares of totalallocated currencies

Table 1. Summary statistics (1973-2013)

\begin{tabular}{|c|c|c|c|c|c|}
\hline Variable & Obs & Mean & Std. Dev. & Min & Max \\
\hline FRS & 164 & 0.224 & 0.258 & $1.00 \mathrm{E}-06$ & 0.803 \\
\hline CA $^{\mathrm{a}}$ & 164 & -25.252 & 185.327 & -798.478 & 286.049 \\
\hline REER & 164 & 105.348 & 15.049 & 61.210 & 140.620 \\
\hline
\end{tabular}

Source: Author's calculation. The variables FRS, CA, and REER represent the share of foreign reserve held by central banks, current account balance, and real effective exchange rate, respectively.

a. Account in billion dollar
Table 2. Summary statistics (1973-2013) by countries

\begin{tabular}{|c|c|c|c|c|c|c|}
\hline Country & Variable & Obs & Mean & Std. Dev. & Min & Max \\
\hline \multirow{3}{*}{ US } & FRS & 41 & 0.650 & 0.081 & 0.506 & 0.803 \\
\hline & $\mathrm{CA}^{\mathrm{a}}$ & 41 & -230.866 & 244.248 & -798.478 & 18.114 \\
\hline & REER & 41 & 108.048 & 10.370 & 95.470 & 138.280 \\
\hline \multirow{3}{*}{ UK } & FRS & 41 & 0.031 & 0.009 & 0.017 & 0.056 \\
\hline & $\mathrm{CA}^{\mathrm{a}}$ & 41 & -23.757 & 28.150 & -119.059 & 8.117 \\
\hline & REER & 41 & $\mid 116.857$ & 11.405 & 99.540 & 140.620 \\
\hline \multirow{3}{*}{ Japan } & FRS & 41 & 0.048 & 0.022 & 0.000 & 0.085 \\
\hline & $\mathrm{CA}^{\mathrm{a}}$ & 41 & 93.960 & 66.348 & -25.117 & 244.616 \\
\hline & REER & 41 & 93.324 & 18.766 & 61.210 & 129.590 \\
\hline \multirow{3}{*}{ Germany } & FRS & 41 & 0.168 & 0.062 & 0.059 & 0.277 \\
\hline & $\mathrm{CA}^{\mathrm{a}}$ & 41 & 59.657 & 99.079 & -49.248 & 286.049 \\
\hline & REER & 41 & 103.161 & 6.062 & 87.420 & 116.230 \\
\hline
\end{tabular}

Source: Author's calculation. The variables FRS, CA, and REER represent the share of foreign reserve held by central banks, current account balance, and real effective exchange rate, respectively.

a. Account in billion dollar

\subsection{Economic Approach}

To investigate the existence of the Triffin dilemma in the current international monetary system, we need to estimate the relationship among reserve shares (FRS), current account balance (CA) and real effective exchange rate (REER); we draw inspiration of the original contradiction of Triffin dilemma, which shows the export of the currency for the international use that constrains the issuing nation to keep its current account balance deficit while the deficit is undermining the value of the currency. The contradiction holds if the current account balance is a negative relationship with the reserve shares and a positive relationship between current account balance and real effective exchange rate. Based on that, the basic economic model is written as equation (1) and (2) as follows,

$$
\begin{aligned}
& F R S_{i t}=f\left(C A_{i t}, R E E R_{i t}\right) \\
& R E E R_{i t}=f\left(F R S_{i t}, C A_{i t}\right)
\end{aligned}
$$

As mentioned in the data chapter, FRS, CA and REER are the reserve shares, current account balance, and real effective exchange rate, respectively. The subscripts $t$ and $i$ stand for the country and time. After the transformations of all the variables, the equation (1) and (2) can be written as follows, 


$$
\begin{aligned}
& \ln F R S_{i t} /\left(1-F R S_{i t}\right)= \\
& f\left(\ln \left[1+C A_{i t}-\min \left(C A_{i}\right)\right], \ln R E E R_{i t}\right) \\
& \ln R E E R_{i t}= \\
& \quad \quad f\left(\ln F R S_{i t} /\left(1-F R S_{i t}\right), \ln \left[1+C A_{i t}-\min \left(C A_{i t}\right)\right]\right)
\end{aligned}
$$

Here, to prove the existence of Triffin dilemma, we expect that $\alpha_{1}$ the coefficient of $\mathrm{CA}$ term in equation (3) is negative significantly while $\beta_{2}$ in equation (4) is positive and significant. Besides, to improve the robustness of the estimation, the panel cointegration test is used to confirm that the three variables are cointegrated and then we can use the non-stationary panel data estimator. Pesaran, Shin, and Smith (1999) introduced a new econometric technique called Pooled Mean-Group (PMG) estimator, which is suitable for the panel data, where the number of time series of observations, $\mathrm{T}$, is relatively large and of the same order of magnitude as $\mathrm{N}$, the number of groups.

The advantage of this estimator allows the intercept, short-run coefficient, and error variance to differ freely across groups, however, it also constraints that all the longrun coefficients are identical. The reason for this estimator to be chosen as that we expect that the puzzle, Triffin dilemma, is supposed to influence by all the countries where their currency is used as international currencies in a similar manner; while the short-run dynamic specification of the countries differs from each other. Therefore, PMG is supposed to match our analysis.

There are three pre-conditions for PMG estimation: The first is that all the variables should be not stationary and are co-integrated so that we could address this assumption with panel unit root tests as well as co-integration test. The second condition is that the slope homogeneity for all the cross sections in the sample panel should be the same. To test the slope homogeneity, the pooled and mean-group estimators can be used.

The pooled estimator estimates the long-run parameters jointly and it maximises the degrees of freedom in the estimation. The pooled estimator is consistent and efficient under the assumption of slope homogeneity, while it is not consistent with the alternative hypothesis. Thus, the meangroup estimator is always consistent, but it is not efficient if the slopes are homogeneous. The third pre-condition is that there is no cross-sectional correlation. To test that, we may use time dummies or subtract the cross-sectional means from the data (Zhang \& Macdonald, 2014).

\section{Results}

To test whether the data set are cross-sectionally correlated, there are two tests suggested in the relevant literature, which are Breusch and Pagan (1980) and Pesaran (2004). Breusch and Pagan (1980) introduced the Lagrange multiplier (LM) that yields the test statistic. Table 3 reports the result from Breusch and Pagan (1980) and Pesaran (2004) and shows that the LM test rejects the null hypothesis of no cross-sectional dependence or independence at 0.01 level, but the CD test does not reject the null hypothesis of no cross-sectional dependence. Damette and Fromentin (2013) claimed that, of all the crosssectional dependence tests, the CD test has the best sample size properties when $T$ (the time period) much exceeds $\mathrm{N}$ (countries), as is the case in our panel. Therefore, we prefer the result of $C D$ test and conclude that the cross-sectional dependence is not true statistically.

Table 3. Cross-sectional Dependence Test

\begin{tabular}{|c|c|c|}
\hline & Breush-Pagan (LM) & Pesaran (CD) \\
\hline Panel & $26.252^{* * *}$ & -1.414 \\
\hline
\end{tabular}
0.01 level.

Next, as we found the cross-sectional dependence is not true, the panel unit roots are preceded without considering the cross-sectional dependence. To identify the order of the integration of the variables, this study uses the tests from Breitung (2000) and Hadri (2000). The reason for using the Breitung (2000) panel unit root test is that a recent largescale Monte Carlo simulation study by Hlouskova and Wagner (2006) found that the Breitung (2000) panel unit root test generally has the highest power and smallest size distortions of any of the so-called first-generation panel unit root tests. Also, tests from Hadri (2000) are selected owing to the Hadri (2000) statement that his tests are appropriate for panel data sets in which $\mathrm{T}$ is large and $\mathrm{N}$ is moderate, such as the Penn World Tables frequently used for crosscountry comparisons. The panel dataset of this study is the property of large $\mathrm{T}$ but the small $\mathrm{N}$, nevertheless, those two tests are relatively powerful than other panel unit root tests.

Table 4 reports Breitung (2000) tests results that the real effective exchange rate variable does not have panel unit root in its level without trend, whereas it is not stationary when with the trend. Besides, Table 4 shows that the first differences of all the three variables are stationary.

Table 5 demonstrates the result of Hadri (2000) LM test, which indicates that the null hypothesis of the Hadri (2000) test is strongly rejected and thus we conclude that all the variables are not stationary. Also, the first difference of all 
the variables are tested and the results show that all the variables in first difference are stationary. Therefore, we conclude that all the variables are non-stationary I (1).

Table 4. Panel Unit Roots Test- Breitung (2000) Tests

\begin{tabular}{|c|c|c|c|}
\hline \multirow{7}{*}{ Level } & Variable & $\begin{array}{c}\lambda-\text {-Statistic } \\
\text { Constant }\end{array}$ & $\begin{array}{c}\lambda \text {-Statistic } \\
\text { Constant and } \\
\text { Trend }\end{array}$ \\
\hline \multirow{3}{*}{ First difference } & FRS & -0.142 & -1.32 \\
\cline { 2 - 4 } & REER & $-1.83^{* *}$ & -0.672 \\
\cline { 2 - 4 } & CA & -0.343 & 1.43 \\
\cline { 2 - 4 } & FRS & $-3.63^{* * *}$ & $-4.99^{* * *}$ \\
\cline { 2 - 4 } & REER & $-6.91^{* * *}$ & $-4.93^{* * *}$ \\
\hline & CA & $-8.32^{* * *}$ & $-7.32^{* * *}$ \\
\hline
\end{tabular}

The variables FRS, CA, and REER represent the share of foreign reserve held by central banks, current account balance, and real effective exchange rate, respectively.

${ }^{* * *},{ }^{* *}$ Rejects the null of panel unit root at the 0.01 and 0.05 level.

Table 5. Panel Unit Roots Test - Hadri (2000) Tests

\begin{tabular}{|c|c|c|c|}
\hline \multirow{4}{*}{ Level } & Variable & $\begin{array}{c}\text { Z-statistic } \\
\text { Constant }\end{array}$ & $\begin{array}{c}\text { Z-statistic } \\
\text { Constant and Trend }\end{array}$ \\
\hline & FRS & $9.094^{* *}$ & $14.338^{* * *}$ \\
\cline { 2 - 4 } & CA & $16.568^{* * *}$ & $4.55^{* * *}$ \\
\cline { 2 - 4 } & REER & $17.863^{\star * *}$ & $19.465^{\star * *}$ \\
\hline \multirow{3}{*}{$\begin{array}{c}\text { First } \\
\text { difference }\end{array}$} & FRS & -1.54 & -2.279 \\
\cline { 2 - 4 } & CA & -1.79 & -1.708 \\
\cline { 2 - 4 } & REER & -0.0014 & -1.051 \\
\hline
\end{tabular}

The variables FRS, CA, and REER represent the share of foreign reserve held by central banks, current account balance, and real effective exchange rate, respectively.

${ }^{* * *}$ Rejects the null of stationary at the 0.01 level.

To test if there is a cointegrated relationship among the three variables we firstly use the first-generation cointegration test from Pedroni (1999, 2000), then we continue with the second-generation cointegration test from Westerlund (2007).

Table 6 is summarized with results from both tests, which points out that four statistics reject the null hypothesis of no cointegration at the 0.05 level in the Pedroni test. But, the vand rho-statistics are not significant. Nevertheless, we think that the cointegration relationship is true for two reasons: (1) four of seven statistics reject the null hypothesis to indicate the existence of a cointegration relationship; (2) the powers of group and panel ADF tests are larger than the others tests among the seven tests (Wagner \& Hlouskova, 2007) and those statistics reject the null hypothesis of no cointegration; other than those, Orsal (2008) claimed that the panel ADF test has the best size and size-adjusted power properties among all the seven statistics of Pedroni tests. Therefore, we conclude that the three variables are co-integrated significantly.
Table 6. Panel Cointegration Tests

\begin{tabular}{|c|c|c|}
\hline \multirow{4}{*}{ Pedroni } & Test & Statistic \\
\hline \multirow{4}{*}{} & Panel v-Statistic & 0.427421 \\
\cline { 2 - 3 } & Panel rho-Statistic & -1.037335 \\
\cline { 2 - 3 } & Panel PP-Statistic & $-1.921338^{* *}$ \\
\cline { 2 - 3 } & Panel ADF-Statistic & $-2.02943^{* *}$ \\
\cline { 2 - 3 } & Group rho-Statistic & -0.668112 \\
\cline { 2 - 3 } & Group PP-Statistic & $-2.254844^{* *}$ \\
\cline { 2 - 3 } & Group ADF-Statistic & $-2.29055^{* *}$ \\
\hline \multirow{4}{*}{ Westerlund } & Gt & $-8.083^{* * *}$ \\
\cline { 2 - 3 } & Ga & $-16.86^{* * *}$ \\
\cline { 2 - 3 } & Pt & $-39.709^{* * *}$ \\
\cline { 2 - 3 } & Pa & $-48.356^{* * *}$ \\
\hline
\end{tabular}

${ }^{* * *},{ }^{* *}$ Rejects the null of no cointegration at the 0.01 and 0.05 levels for Pedroni tests. ${ }^{* * *}$, ${ }^{* *}$ Rejects the null of cointegration at the 0.01 and 0.05 levels for Westerlund tests. All the variables tested are the adjusted (see the detail in the data chapter).

Next, we conduct the second-generation cointegration tests developed by Westerlund (2007) and Westerlund and Edgerton (2007). The Westerlund cointegration test (2007), based on the Durbin-Hausman principle as developed by Choi (1994), is similar to Bai and Ng's (2004) unit root test and Moon and Perron (2004) because the two statistics $\mathrm{DHg}$ and $\mathrm{DHp}$ are based on the estimation of a common component from the regression errors in order to derive the test on the residual idiosyncratic component.

As Westerlund (2007) explained, because the test is constructed under the assumption of a unit root in the idiosyncratic errors, the null hypothesis is the absence of cointegration, while the alternative is formulated as that there are at least some countries for which there is a cointegrating relationship. As a consequence, we cannot identify the countries where the variables are really cointegrated in the case of rejection. The Westerlund and Edgerton (2007) test is a good complement because it was developed on the null that takes cointegration for the panel as a whole.

As we see in Table 6, all the test statistics are significant at 0.01 level and indicate to reject the null hypothesis of no cointegration statistically, thus we conclude that the cointegrating relationship among the three variables is the presence. The results from both tests are consistent; therefore, there is more evidence to confirm the existence of panel cointegration. Since all the pre-conditions are fulfilled by the panel data used in this study, where we find the variables reserve shares held by central banks and current account balance and real effective exchange rate are cointegrated together and in a simultaneous long-term relationship. Therefore, we continue the analysis with the Pool Mean-Group (PMG) estimation in the following to identify the dynamic of economic and market in the long-run and short-run in the international currency issuing countries, 
and thus the simultaneous transmission mechanism among the three variables can be investigated to show if the Triffin dilemma still exists in the monetary system.

Table 7. Pooled Mean-Group Estimation Results

\begin{tabular}{|c|c|c|c|}
\hline & & (1) & (2) \\
\hline \multirow[t]{5}{*}{ Short-run } & & $\Delta \mathrm{FRS}$ & $\triangle$ REER \\
\hline & Constant & 7.105 & $-1.19^{*}$ \\
\hline & $\triangle$ REER & 0.126 & \\
\hline & $\Delta \mathrm{CA}$ & 2.1 & $-0.185^{\star}$ \\
\hline & $\Delta \mathrm{FRS}$ & & 0.0341 \\
\hline \multirow[t]{4}{*}{ Long-run } & & FRS & REER \\
\hline & REER & $2.50^{*}$ & \\
\hline & CA & $-7.64^{* *}$ & $1.88^{* \star \star}$ \\
\hline & FRS & & 0.034 \\
\hline Speed of adjustment & ECT & -0.193 & $-0.150^{*}$ \\
\hline \multirow[t]{5}{*}{ Joint or Strong Causality } & Joint (REER and CA) & $5.86^{*}$ & \\
\hline & \multicolumn{2}{|l|}{ Joint (FRS and CA) } & $20.66^{\star \star *}$ \\
\hline & Joint (ECT and $\triangle$ REER) & 3.13 & \\
\hline & Joint (ECT and $\triangle \mathrm{CA})$ & 3.19 & 3.9 \\
\hline & \multicolumn{2}{|l|}{ Joint (ECT and $\Delta \mathrm{FRS}$ ) } & 3.86 \\
\hline
\end{tabular}

The variables FRS, CA, and REER represent the share of foreign reserve held by central banks, current account balance, and real effective exchange rate, respectively. ${ }^{*},{ }^{* *},{ }^{* * *}$ Rejects the null of panel unit root at the $0.10,0.05,0.01$ level. All the variables are the adjusted (see the detail in the data chapter).

In Table 7, we estimated the impact of the real effective exchange rate (REER) and the current account balance (CA) on the reserve shares held by central banks (FRS) in the column (1). We found that both the real effective exchange rate and the current account balance do not affect reserve share significantly in the short term. However, for the longrun relationship, we could see that the real effective exchange rate has a positive effect on reserve shares at 0.1 significant level, and the current account balance has a negative effect on reserve share at 0.05 significant level.

This empirical result is consistent with the reality of the international monetary system and the process of the internationalization of a currency for two reasons; (1) internationalisation of a currency is a long-run job as if the issuer intends to attract the holder to reserve its currency, the issuer has to show a long-term confidence in its currency by continuous output (e.g., run current account deficit); (2) a nation cannot influence its reserve share held by central banks through the publishing of any transient economic policies that would simulate the position of its currency.

In Column (2), we investigated the impact of the current account balance and the reserve share on the real effective exchange rate and found that the effect of the current account balance is significant at 0.01 level, which is in the direction anticipated for the long-run estimates. One point of interest is that the short-run estimates yield the negative coefficient of the current account balance, which is not consistent with the long-run estimates. It is noted that the countries under studied are the international currency issuing countries that commonly settle their international trade with their own currencies, such as the Yen is being used in the trades of Japan.

Therefore, either current account deficit or surplus would affect the demand for the currency in the very short term, thereby influencing the dynamic of the currency value. For example, we may learn that higher demand caused by the current account balance deficit of which can push up the currency value in the short-run. In addition, we see that the coefficient of the reserve share in the short-run estimates of Column (2) is in the expected direction but is not significant. A positive sign indicates the short-term demand by other central banks is likely to boost the price of the currency.

Now consider Column (1) together with Column (2), the coefficients of the current account balance in both long-run estimations are on the opposite directions, in accordance with which we claim that the Triffin dilemma still exists in the long run. For Column (1), issuing countries run current account deficit to supply their currency to the external parties and eventually expand the reserve share held by central banks in the long-run; meanwhile, for Column (2), the long-run results show positive causality from current account balance to the real effective exchange, in other words, the decrease in current account balance lowers real effective exchange rate.

To improve the robustness of the study, we consider the sample without the United States and its dollar, as discussed in the section of historical review, the dollar has been dominating and playing the most important role in the international monetary system since the end of the World War I. Thus, we have a suspicion of that if there is no dollar, the impact of Triffin dilemma would not exist. By changing the sample, we proceed with the cross-sectional dependence tests, panel unit root test, and panel cointegration again. The results indicate that the preconditions of PMG estimator can be fulfilled (See tests results in Appendix A-D).

Table 8 reports PMG estimation for the non-dollar panels and shows that it is still significant that the current account has a negative relationship with the reserve shares while having in proportion to the real effective exchange rate in the long run, the coefficients do not change a lot. In addition, the short-run estimates are identical to those in Table 7 . In other words, the result of Table 8 is consistent with Table 7. 
Table 8. Pooled Mean-Group Estimation for Non-dollar Panel

\begin{tabular}{|c|c|c|c|}
\hline & & (a) & (b) \\
\hline \multirow[t]{5}{*}{ Short-run } & & $\Delta \mathrm{FRS}$ & $\triangle$ REER \\
\hline & Constant & 9.50 & $-1.60^{\star *}$ \\
\hline & $\Delta$ REER & 0.196 & \\
\hline & $\Delta \mathrm{CA}$ & 2.79 & $-0.246^{*}$ \\
\hline & $\Delta \mathrm{FRS}$ & & 0.0486 \\
\hline \multirow[t]{4}{*}{ Long-run } & & FRS & REER \\
\hline & REER & $2.47^{*}$ & \\
\hline & CA & $-7.62^{* \star}$ & $1.90^{* \star *}$ \\
\hline & FRS & & 0.033 \\
\hline \multirow{6}{*}{$\begin{array}{l}\text { Speed of adjustment } \\
\text { Joint or Strong Causality }\end{array}$} & ECT & $-0.258^{*}$ & $-0.198^{* \star}$ \\
\hline & Joint (REER and CA) & $5.89^{*}$ & \\
\hline & \multicolumn{2}{|l|}{ Joint (FRS and CA) } & $20.72^{* \star \star}$ \\
\hline & Joint (ECT and $\triangle$ REER) & $5.43^{*}$ & \\
\hline & Joint (ECT and $\Delta \mathrm{CA})$ & 4.45 & $5.75^{*}$ \\
\hline & \multicolumn{2}{|l|}{ Joint (ECT and $\triangle F R S$ ) } & $6.12^{* *}$ \\
\hline
\end{tabular}

The variables FRS, CA, and REER represent the share of foreign reserve held by central banks, current account balance, and real effective exchange rate, respectively. ${ }^{*},{ }^{* *},{ }^{* * *}$ Rejects the null of panel unit root at the $0.10,0.05,0.01$ level. All the variables are the adjusted (see the detail in the data chapter).

\section{Policy Recommendations}

As discussed in the historical review, an international currency enjoys a few benefits. However, our results have shown that the Triffin dilemma exists in the current International Monetary System. There is a cost to those issuing countries of international currencies. Thus far, there is no sound solution that can be applied to solve the problem. Nevertheless, we think it is possible to reduce the impact of Triffin dilemma gradually. Three steps are suggested:

\subsection{Currency Swap Mechanisms}

The international currency issuing countries like the United States can construct the currency swap mechanism. On one hand, the currency swap does not influence the current account balance; on the other hand, if the currency swap mechanism is well developed, it could be helpful for the potential financial crisis because it can release the liquidity pressure for the troubled states. However, due to unequal wealth between nations, the issuing countries are not willing to hold the currencies of other countries. Even if the countries are willing to do so, this suggestion still cannot improve the economic situation of the issuing countries, for instance, if the current account continues to lose, it will eventually influence the confidence of the currency.

\subsection{Multi-polar Monetary System}

The current international monetary system is dominated by dollar, of which reserve share held by central banks takes $61.2 \%$ of all the reserve currencies allocated by the respective central bank. Euro is only $24.4 \%$ of which is ranked as the second, followed by Yen and Pound. So, we see that the shares of currencies are not balanced. We suggest other countries, rather than the U.S., to internationalize their currencies so that ultimately the international monetary system would be more balanced and competitive. Although this suggestion cannot be used for solving the Triffin dilemma, under the competitive aspect, issuing countries could reinforce check and balance so that they would not only consider their own domestic economies but also the external economies in the long-run.

\subsection{Supranational Currency System}

As previously discussed, once we have a balanced monetary system, it will be possible to implement a supranational currency. Imagine if there are three more "United States" located in Europe, Africa, and Asia, where the four currencies equally dominate the World, we absolutely believe that the supranational currency can be created through the four equally give up the hegemony of their currencies. This is analogous to the current Eurozone, where the seventeen countries do not differ so much from each other in most of the aspects; thus, the euro can be created. With a supranational currency to act as a global reserve currency, not only the fundamental problem of Triffin dilemma can be overcome as the issuance of currency is not related to the current account balance of any specific country; but also, it can avoid the negative externalities for the global economy caused by the policy from the reserve currency of issuing countries. Other than those, it allows the global to equally share the seigniorage.

To sum up our suggestions, there are three steps need to be taken. For the first step, strengthening the currency swap mechanism in the short term; for the second step, forming a competitive multipolar international monetary system so that it gradually achieves a power-balanced system; finally, building a global entity to issue a supranational currency replacing all the currencies. It is not a simple utopian dream, we believe the supranational currency can be actualized if following those three steps, therefore, the Triffin dilemma will not exist any longer. 


\section{Conclusion}

This study uses the data set on four major international currencies from the year 1973 to 2013 with Pooled MeanGroup (PMG) estimator, to re-examine whether Triffin dilemma still exists or not through investigating relationships between reserve share and current account balance and real effective exchange rate. The evidence we found from the results indicates that Triffin dilemma exists only in the long run, for the long run, the current account balance is proportionate to the increased real effective exchange rate while varies inversely with the reserve shares, however, it is not clear for the short-run based on the results. Also, we reinvestigated the non-dollar panels and find that others currencies than dollar suffer Triffin dilemma in the long-run as well.

The key point is that the issuing countries not only need to run the current account balance deficit to supply their currencies to the rest of the world needs, but they are also required to keep the value of the currencies at least not depreciate in the condition of the current account balance deficit. In other words, the origin of the contradiction in the current account balance cannot be in both directions at the same time. Based on our result, the reserve shares, current account balance, and real effective exchange rate are cointegrated. In other words, they share a common linear trend in the long run.

These countries need to focus on their long-term current account balance as the deficit has a negative impact on the currency value of which would eventually undermine the monetary system. Hence, the conceptual framework of the Triffin dilemma is reflected in our estimation. To overcome Triffin dilemma, we suggest three steps and then eventually create a supranational currency to replace all the currencies.

\section{References}

Bai, J., \& Ng, S. (2004). A PANIC attack on unit roots and cointegration. Econometrica, 72(4), 1127-1177.

Breitung, J. (2000). The local power of some unit root tests for panel data. In: Nonstationary Panels, Panel Cointegration, and Dynamic Panels, Baltagi, B. H. (Ed.). Amsterdam: Elsevier, pp. 161-177.

Breusch, T. S., \& Pagan, A. R. (1980). The Lagrange multiplier test and its applications to model specification in econometrics. The Review of Economic Studies, 47(1), 239-253.

Chinn, M., \& Frankel, J. A. (2007). Will the euro eventually surpass the dollar as leading international reserve currency?. In G7 Current account imbalances: sustainability and adjustment (pp. 283-338). Chicago, IL: University of Chicago Press.

Choi, I. (1994). Durbin-Hausman tests for cointegration. Journal of Economic Dynamics and Control, 18(2), 467-480. doi:https://doi.org/10.1016/0165-1889(94) 90018-3

Damette, O., \& Fromentin, V. (2013). Migration and labour markets in OECD countries: A panel cointegration approach. Applied Economics, 45(16), 2295-2304.

Eichengreen, B. (2011). The renminbi as an international currency. Journal of Policy Modeling, 33(5), 723-730.

Eichengreen, B., \& Frankel, J. A. (1996). On the SDR: reserve currencies and the future of the international monetary system (No. C96-068). Berkeley, CA: University of California at Berkeley. Retrieved January 2, 2017, Available at: https://sites.hks.harvard.edu/fs/jfrankel/SDRCIDwp.3 JF.PDF

Hadri, K. (2000). Testing for stationarity in heterogeneous panel data. The Econometrics Journal, 3(2), 148-161.

Hlouskova, J., \& Wagner, M. (2006). The performance of panel unit root and stationarity tests: results from a large-scale simulation study. Econometric Reviews, 25(1), 85-116.

International Monetary Fund (2017), Currency composition of official foreign exchange reserves (COFER). Retrieved April 12, 2018, from: http://www.imf.org/en/ News/Articles/2017/03/31/pr17108-IMF-ReleasesData-on-the-Currency-Composition-of-ForeignExchange-Reserves on 1 April 2017

Lee, J. W. (2010). Will the renminbi emerge as an international reserve currency?. Manila, Philippines: Asian Development Bank.

Li, D. D., \& Liu, L. (2010). RMB Internationalization: Empirical and Policy Analysis. In Currency Internationalization, Global Experiences, and Implications for the Renminbi (pp.167-185), New York: Palgrave Macmillan.

McCauley, R. N. \& Schenk, C. R. (2014). Reforming the international monetary system in the 1970s and 2000s: Would an SDR substitution account have worked?. BIS Working Papers No 444, March 2014.

McMillan, M. S., \& Rodrik, D. (2011). Globalization, structural change, and productivity growth (No.17143). Cambridge, MA: National Bureau of Economic Research. Retrieved January 2, 2017, from: http://www.nber.org/papers/w17143

Moon, H. R., \& Perron, B. (2004). Testing for a unit root in panels with dynamic factors. Journal of Econometrics, 122(1), 81-126.

Obstfeld, M., \& Rogoff, K. (2005). Global current account imbalances and exchange rate adjustments. 
Brookings Papers on Economic Activity, 1, 67-146. Washington, DC: Brookings Institution.

Obstfeld, M., \& Rogoff, K. (2007). The Unsustainable U.S. Current Account Position Revisited. In Richard H. Clarida (ed.). G7 Current Account Imbalances: Sustainability and Adjustment (pp.339-375), University of Chicago Press. Available at: http://www.nber.org/chapters/c0127.pdf

Örsal, K. D. D. (2008). Comparison of panel cointegration tests. Economics Bulletin, 3, 1-20.

Padoa-Schioppa, T. (2010). The ghost of Bancor: The economic crisis and global monetary disorder. Speech presented at Louvain-la-Neuve. Retrieved April 12, 2018, from: http://www.notre-europe.eu /media/speech-tps-louvainlaneuve-25.02.2010.pdf? pdf $=$ ok.

Pesaran, M. H., Shin, Y., \& Smith, R. P. (1999). Pooled mean group estimation of dynamic heterogeneous panels. Journal of the American Statistical Association, 94(446), 621-634.

Pesaran, M. H. (2004). General diagnostic tests for cross section dependence in panels. Cambridge: University of Cambridge. doi: https://doi.org/10.17863/CAM.5113

Pedroni, P. (1999). Critical values for cointegration tests in heterogeneous panels with multiple regressors. Oxford Bulletin of Economics and Statistics, 61(S1), 653-670.
Pedroni, P. (2000). Fully Modified OLS for Heterogeneous Cointegrated Panels. Advances in Econometrics, 15, 93-130.

Steiner, A. (2014). Current account balance and dollar standard: Exploring the linkages. Journal of International Money and Finance, 41(Supplement C), 65-94. doi: https://doi.org/10.1016/j.jimonfin.2013.10.005

Triffin, R. (1960). Gold and the Dollar Crisis: The Future of Convertibility (Vol. 960). New Haven, CT: Yale University Press.

Triffin, R. (1964). Evolution of the International Monetary System: Historical Reappraisal and Future Perspectives. Princeton, NJ: International Finance Section, Department of Economics, Princeton University.

Triffin, R. (1978). Gold and the Dollar Crisis: Yesterday and Tomorrow. Princeton, NJ: International Finance Section, Department of Economics, Princeton University.

Westerlund, J. (2007). Testing for error correction in panel data. Oxford Bulletin of Economics and Statistics, 69(6), 709-748.

Westerlund, J., \& Edgerton, D. L. (2007). A panel bootstrap cointegration test. Economics Letters, 97(3), 185-190

Zhang, G., \& MacDonald, R. (2014). Real Exchange Rates, the Trade Balance, and Net Foreign Assets: LongRun Relationships and Measures of Misalignment. Open Economies Review, 1-19.

Zhou, X. (2009). The reform of the international monetary system. Equilibrium, 13(2), 161-166. 